ISSN 0258-7122 (Print), 2408-8293 (Online)

Bangladesh J. Agril. Res. 42(1): 77-85, March 2017

\title{
EFFECT OF NITROGEN ON GROWTH AND YIELD ON MUNGBEAN IN LOW NUTRIENT SOIL
}

\author{
M. A. RAZZAQUE ${ }^{1}$, M. M. HAQUE ${ }^{2}$ AND M. A. KARIM ${ }^{3}$
}

\begin{abstract}
A pot experiment was conducted at Bangabandhu Sheikh Mujibur Rahman Agricultural University, Gazipur during kharif II season of 2011 to investigate the growth, dry matter production and yield of mungbean genotypes under nutrient stress soil. Ten mungbean genotypes viz., IPSA-12, GK-27, IPSA-3, IPSA-5, ACC12890053, GK-63, ACC12890055, BARI Mung-6, BUmug- 4 and Bina moog- 5 and six nitrogen fertilizer levels viz., 0, 20, 40, 60, 80 and $100 \mathrm{~kg}$ $\mathrm{N}$ ha $^{-1}$ were included as experimental treatments. Results revealed that increasing nitrogen level in nutrient stress soil increased growth and dry matter production up to $60 \mathrm{~kg} \mathrm{~N} \mathrm{ha}^{-1}$ irrespective of genotype and thereafter decreased. Among the mungbean genotype IPSA 12 showed maximum leaf area, dry matter production and seed yield (14.22 $\left.\mathrm{g} \mathrm{plant}^{-1}\right)$ in nutrient stress soil. The lowest seed yield (7.33 $\mathrm{g} \mathrm{plant}^{-1}$ ) was recorded in ACC12890053 under control condition.
\end{abstract}

Keywords: Mungbean genotype, Nutrient stress, Dry matter, Seed yield.

\section{Introduction}

Mungbean is one of the most important pulse crop in the south Asia. It is primary source of high quality, easily digestible protein and provides vitamin A, vitamin $\mathrm{C}$, zinc and foliate to the predominantly vegetarian population of south Asia (Chanda, 2007).

However, yield of mungbean in south Asia is very low due to different causes like, nutrient stress, salinity, rainfall and lack of suitable variety. Among them mungbean cultivation under nutrient stress soil and also low utilization of $\mathrm{N}$ fertilizer, where as optimum $\mathrm{N}$ fertilizer enhance grain growth and development.

It is now well established that despite nitrogen fixation, $\mathrm{N}$ alimentation in legumes is limiting factor in terms of either quantitative (seed) or qualitative $(\mathrm{N})$ yields. In fact, young plants find their initial nitrogen requirements through soil mineral nitrogen. After nodules have been established, $\mathrm{N}$ fixation succeeds to assimilation, reaches peak at pod developing stage and declines thereafter. Later, most of the seed filling is achieved by the redistribution of $\mathrm{N}$ from vegetative plant organs to the developing seeds. The beneficial effect of applied nitrogen is to retained more leaf area causing accelerated photosynthetic rate which led to

${ }^{1}$ Senior Scientific Officer, T\&C, Bangladesh Agricultural Research Institute (BARI), Gazipur, ${ }^{2 \& 3}$ Professor, Department of Agronomy, Bangabandhu Sheikh Mujibur Rahman Agricultural University (BSMRAU), Gazipur, Bangladesh. 
more dry matter production and consequently higher yield per plant (Dahatonde and Nalamwar, 1996; Sushant et al., 1999). Such improvement in yield components and yield of mungbean by applied nitrogen was also reported by many researchers. Patra and Bhattacharyya (1997) observed that the highest seed yield and yield components were obtained by applied urea at the rate of $25 \mathrm{~kg} \mathrm{~N}$ $\mathrm{ha}^{-1}$. Ashraf, (2001); Mahboob and Asghar (2002) also found that number of pods per plant, seeds per pod, 1000-seed weight were significantly affected by the application of nitrogen from 20 to $50 \mathrm{~kg} \mathrm{ha}^{-1}$. The present study was therefore, aimed to evaluate the effect of nitrogen levels on growth, dry matter production and yield of mungbean genotypes under nutrient stress condition.

\section{Materials and Methods}

The pot experiment was conducted at Bangabandhu Sheikh Mujibur Rahman Agricultural University, Gazipur during kharif II (August to November) season of 2011 of AEZ 28. The experimental site was located at $24^{\circ} 09^{\prime} \mathrm{N}$ latitude and $90^{\circ} 26^{\prime} \mathrm{E}$ longitude and $8.4 \mathrm{~m}$ above the sea level which is characterized by subtropical climate. The physical and chemical properties of soil are presented in table 1 . The soil was sandy loam having $6.9 \mathrm{pH}, 0.538 \%$ organic matter, $0.05 \% \mathrm{~N}, 0.16 \mathrm{mg} \mathrm{kg}^{-1} \mathrm{P}, 0.85 \mathrm{meq} \% \mathrm{~K}$, and $0.70 \mathrm{mg} \mathrm{kg}^{-1}$ and the Rhizobium count was $4.55 \times 10^{8} \mathrm{~g}$ soil. Each pot containing $12 \mathrm{~kg}$ soil was fertilized with 32 $\mathrm{kg} \mathrm{K} \mathrm{ha}{ }^{-1}$ in the form of muriate of potash and mixed thoroughly with soil

The experiment was established in pot containing $12 \mathrm{~kg}$ soil collected from codda bazaar which belongs in codda series. Experimental soil was fertilized $25 \mathrm{~kg} \mathrm{P}$ and $32 \mathrm{~kg} \mathrm{~K} \mathrm{ha}^{-1}$ in the form of triple super phosphate and muriate of potash, respectively and incorporated thoroughly into soil. The experiment was laid out in completely randomized design (CRD) with 4 replications. There were 10 genotypes like IPSA 12, GK 27, IPSA 3, IPSA 5, ACC12890055, GK 63, ACC12890053, BUmug 4, BARI Mung 6 and Bina moog 5 and six level of nitrogen $0,20,40,60,80$ and $100 \mathrm{~kg} \mathrm{~N} \mathrm{ha}^{-1}$ as treatment variable and applied at 15 days after sowing.

Seeds were sown on 31 August, 2011. For uniform germination, a light irrigation was given immediately after sowing of seeds., the plants were thinned at first trifoliate stage and 4 plants was remained maintained for recorded growth parameter and one plants remained finally for seed yield in pot. All agronomic management and plant protection measures were kept uniform during the whole growing period of mungbean. Data on growth parameters, dry matter partitioning and yield were recorded. Leaf area were measured using automatic leaf area meter at $50 \%$ flowering stage. 
Table 1. Physical and chemical properties of the experimental soil before sowing

\begin{tabular}{lc|c}
\hline Soil properties & Present value & Critical limit \\
\hline Sand (\%) & 62.23 & - \\
Silt (\%) & 21.77 & - \\
Clay (\%) & 16.00 & - \\
Soil pH & 6.90 & - \\
Textural class & Sandy loam & - \\
Rhizobium/g soil & $4.55 \times 10^{8}$ & - \\
Total N (\%) & 0.05 & 0.10 \\
Available P (ppm) & 0.16 & 8.00 \\
Exchangeable K (meq/100g soil) & 0.85 & 0.08 \\
Available S (ppm) & 7.00 & 8.00 \\
Available B (ppm) & 0.15 & 0.16 \\
Available Zn (ppm) & 0.25 & 0.50 \\
Exchangeable Ca (meq/100g soil) & 14.83 & 2.00 \\
Exchangeable Mg (meq/100g soil) & 1.76 & 0.50 \\
CEC meg/100g soil & 6.904 & $3-7.5$ \\
Organic matter (\%) & 0.536 & - \\
\hline
\end{tabular}

For dry matter partitioning shoots and roots were oven dried at $70^{\circ} \mathrm{C}$ to constant weight. Data on different parameters were subjected to statistical analysis and means compared by DMRT at 5\% level of probability.

\section{Results and Discussion}

\section{Leaf area}

Leaf area of mungbean was increased with the increasing of $\mathrm{N}$ fertilizer up to 60 $\mathrm{kg} \mathrm{ha}^{-1}$ in most of the genotypes and thereafter decreased with further increase of applied nitrogen (Fig. 1). As N is constituent of enzyme and nucleic acids, it is essential for the development of new cells particularly under $\mathrm{N}$ deficient soil. Thus one of the obvious manifestations of $\mathrm{N}$ limitation is in the inhibition of leaf area development under low N environment (Sinclair and Vandez. 2002). Other authors (Gimenez et al., 1994; Vos and Putten, 1998) also observed that substantial decrease in leaf area of different field crops under $\mathrm{N}$ deficiency condition. This is consistent with present study that the inability to generate new cells for expanding leaf area under $\mathrm{N}$ deficient soil. Genotypic variation in leaf area development at various $\mathrm{N}$ levels is conspicuous and it was the highest in 
genotype, IPSA 12. This genotype maintained the highest leaf area both under deficient $\left(416 \mathrm{~cm}^{2}\right)$ and sufficient $\left(605 \mathrm{~cm}^{2}\right) \mathrm{N}$ condition.

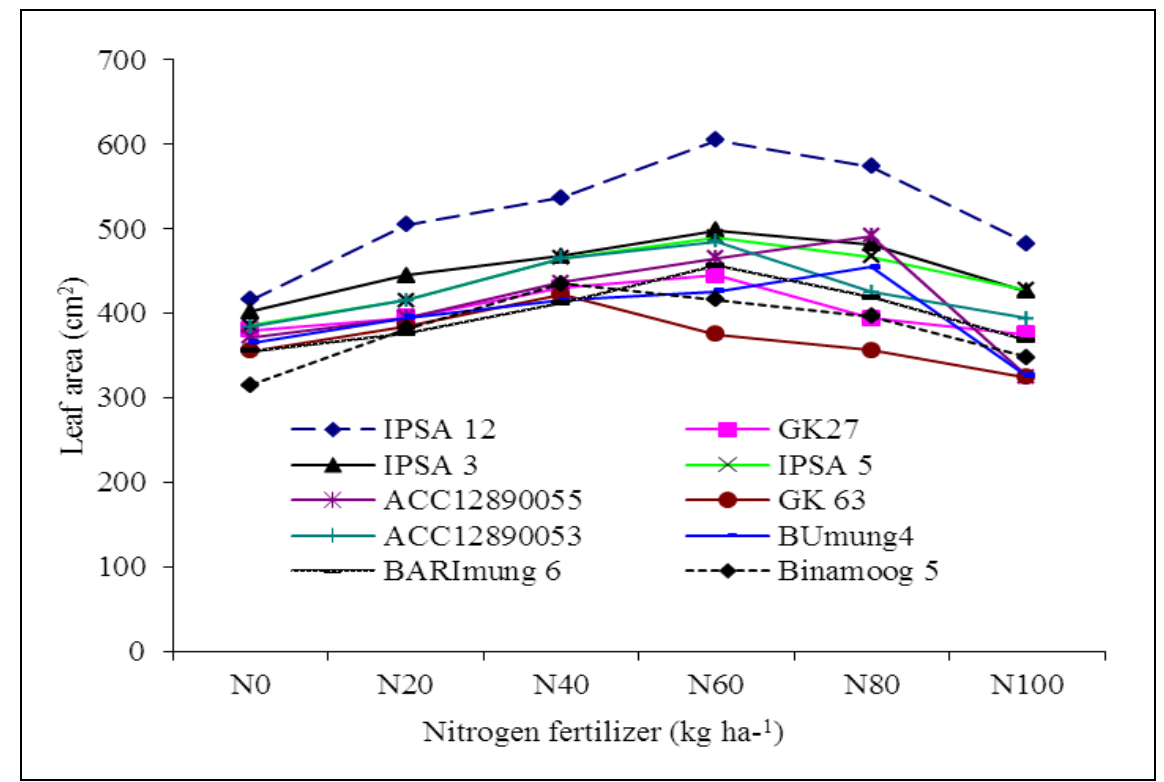

Fig. 1. Leaf area development (trifoliate stage) of mungbean genotypes under different levels of nitrogen fertilizer.

\section{Dry matter accumulation}

Accumulation of dry matter was increased with the increasing $\mathrm{N}$ levels but it peaked (at 40 or $60 \mathrm{~kg} \mathrm{~N} \mathrm{ha}^{-1}$ ) of different mungbean genotypes (Fig. 2). The lowest dry matter was accumulated in plants of control treatment and lower level of $\mathrm{N}$ fertilizer (Fig. 2). Accumulation of lower dry matter at $\mathrm{N}$ deficient conditions might be due to internal nutrient stress of plant which caused reduction in cell division, cell elongation, carbohydrate synthesis and hence the growth was reduced (Karmar, 1988). These results agreed with Akhtaruzzaman (1998) in mungbean and Matsunaga et al. (2008) in cowpea that crops grown under lower $\mathrm{N}$ levels accumulated less dry matter and inhibited the crop growth. Genotypic variation in dry matter accumulation revealed that the genotype IPSA 12 grown at $60 \mathrm{~kg} \mathrm{~N} \mathrm{ha}^{-1}$ accumulated the highest dry matter $\left(30.25 \mathrm{~g} \mathrm{plant}^{-1}\right)$ and it was the lowest $\left(16.26 \mathrm{~g} \mathrm{plant}^{-1}\right)$ in genotype Bina Moog-5.

Considering dry matter accumulation in root, the highest $\left(1.12 \mathrm{~g} \mathrm{plant}^{-1}\right)$ the genotype IPSA 12 grown under $60 \mathrm{~kg} \mathrm{~N} \mathrm{ha}^{-1}$. Conversely, the genotype IPSA 5 accumulated more dry matter in leaves $\left(7.93 \mathrm{~g} \mathrm{plant}^{-1}\right)$ and in stem $(5.86 \mathrm{~g}$ plant $^{-1}$ ) which are supposed to be less efficient in yield formation of mungbean. 

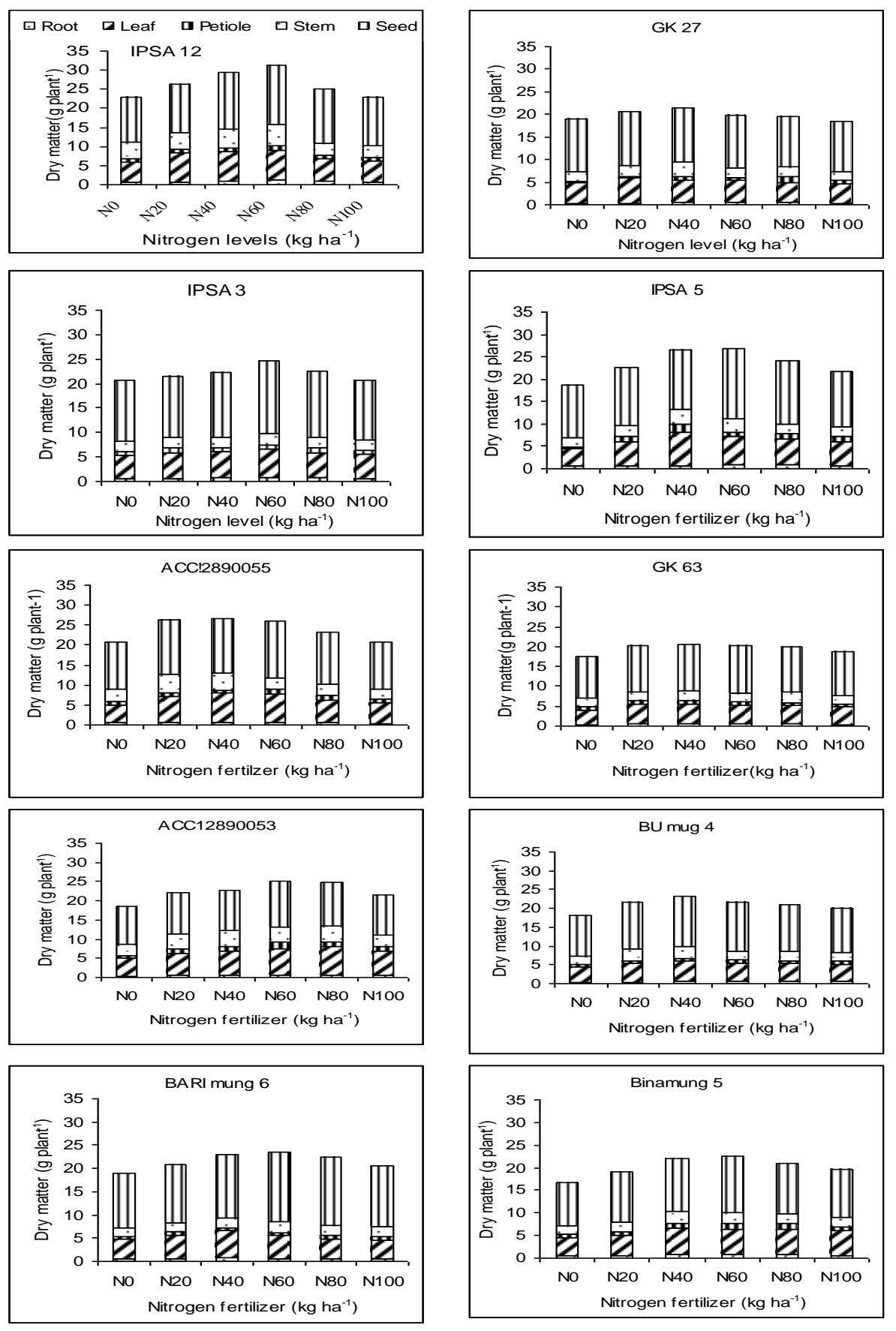

Fig. 2. Pattern of dry matter partitions (trifoliate stage) in mungbean genotypes under different nitrogen levels. 


\section{Crop growth}

Nitrogen fertilizer influenced profoundly on crop growth rate of mungbean. Increase of nitrogen fertilizer increased crop growth rate for all the genotypes up to $60 \mathrm{~kg} \mathrm{ha}^{-1}$ and further increase nitrogen fertilizer decreased the growth rate of mungbean (Fig. 3). It might be due to immobilization of nitrogen fertilizer which did not involve in physiological activities in plant. Crop growth rates further decreased after pod development stage and it is likely that photosynthetic capacity of the plant might have decreased at this stage because of reduction of leaf area. However, the genotype IPSA 12 produced the maximum leaf area which exhibited the highest crop growth rate $\left(0.62 \mathrm{~g} \mathrm{plant}^{-1}\right.$ day $\left.^{-1}\right)$.
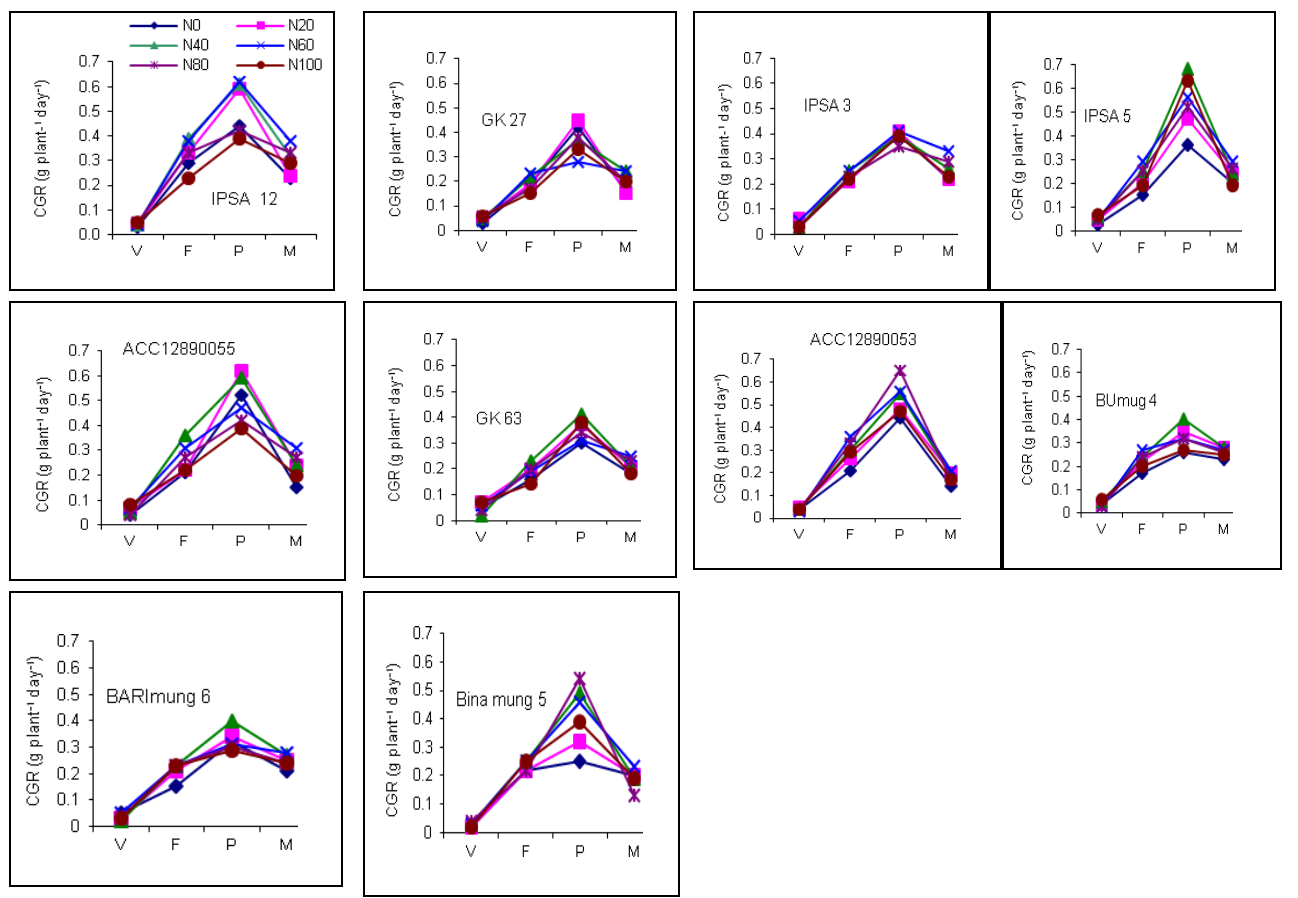

Fig. 3. Crop growth rate of mungbean genotypes as affected by different nitrogen levels ( $\mathrm{V}=$ Vegetative, $\mathrm{F}=$ Flowering, $\mathrm{P}=$ pod developing, $\mathrm{M}=$ Maturity).

\section{Pods per plant}

Number of pods per plant of mungbean genotypes significantly influenced by different $\mathrm{N}$ levels. Increasing nitrogen level led to increase pod plant ${ }^{-1}$ up to 60 $\mathrm{kg} \mathrm{N} \mathrm{ha}^{-1}$ and thereafter decreased (Table 2). These results are in conformity with the findings of (Patra and Parner, 1991) who reported that pod per plant of mungbean increased with application of nitrogen fertilizer and excess application reduced pod number of mungbean. 
There were genotypic variations in pod development in variable to $\mathrm{N}$ level where the genotype IPSA 12 produced the highest pods / plant at $60 \mathrm{~kg} \mathrm{~N} \mathrm{ha}^{-1}(30.16)$. The lowest number of pods (16.16) per plant was recorded in genotype GK 63 with highest $\mathrm{N}$ dose but it was identical with of Bina moog 5 (16.83) with o kg $\mathrm{N} \mathrm{ha}^{-1}$. These results are supported by Ashraf (2001) that number of pods per plant was significantly affected by the application of $\mathrm{N}$ fertilizer. These means that mungbean genotypes require additional $\mathrm{N}$ for better pod development although it is capable to fix atmospheric $\mathrm{N}$ through rhizobium species living in root nodules (Anjum et al., 2006).

Table 2. Number of pods per plant of mungbean genotype as affected by nitrogen levels

\begin{tabular}{l|ccc|c|c|c}
\hline \multirow{2}{*}{ Genotype } & \multicolumn{6}{c}{ Nitrogen level } \\
\cline { 2 - 7 } & $\mathrm{N}_{0}$ & $\mathrm{~N}_{20}$ & $\mathrm{~N}_{40}$ & $\mathrm{~N}_{60}$ & $\mathrm{~N}_{80}$ & $\mathrm{~N}_{100}$ \\
\hline IPSA 12 & $22.00 \mathrm{cA}$ & $24.83 \mathrm{bcA}$ & $27.50 \mathrm{bA}$ & $30.16 \mathrm{aA}$ & $26.16 \mathrm{bA}$ & $22.66 \mathrm{cA}$ \\
GK 27 & $20.00 \mathrm{bA}$ & $22.50 \mathrm{abAB}$ & $23.60 \mathrm{aB}$ & $23.50 \mathrm{aC}$ & $22.33 \mathrm{abB}$ & $19.66 \mathrm{bB}$ \\
IPSA 3 & $19.66 \mathrm{cAB}$ & $22.16 \mathrm{bAB}$ & $23.16 \mathrm{bB}$ & $25.16 \mathrm{aB}$ & $22.50 \mathrm{bB}$ & $20.33 \mathrm{bcB}$ \\
IPSA 5 & $21.83 \mathrm{bcA}$ & $25.33 \mathrm{aA}$ & $26.33 \mathrm{aA}$ & $27.50 \mathrm{aB}$ & $26.00 \mathrm{aA}$ & $23.16 \mathrm{bA}$ \\
ACC12890055 & $20.16 \mathrm{cA}$ & $23.00 \mathrm{abAB}$ & $23.16 \mathrm{abB}$ & $25.00 \mathrm{aB}$ & $21.66 \mathrm{bB}$ & $20.83 \mathrm{bcB}$ \\
GK 63 & $18.83 \mathrm{cB}$ & $21.33 \mathrm{bB}$ & $21.63 \mathrm{bC}$ & $23.33 \mathrm{aC}$ & $22.33 \mathrm{abB}$ & $16.16 \mathrm{cC}$ \\
ACC12890053 & $20.33 \mathrm{cA}$ & $22.00 \mathrm{bcAB}$ & $22.66 \mathrm{bC}$ & $25.83 \mathrm{aB}$ & $22.00 \mathrm{bB}$ & $22.16 \mathrm{bA}$ \\
BU mug 4 & $19.00 \mathrm{cAB}$ & $22.00 \mathrm{bAB}$ & $25.16 \mathrm{aAB}$ & $24.16 \mathrm{aC}$ & $21.83 \mathrm{bBC}$ & $21.00 \mathrm{bcAB}$ \\
BARI Mung 6 & $18.93 \mathrm{cB}$ & $20.50 \mathrm{bB}$ & $22.50 \mathrm{abC}$ & $23.33 \mathrm{aC}$ & $22.33 \mathrm{aB}$ & $20.83 \mathrm{bBC}$ \\
Bina moog 5 & $16.83 \mathrm{dC}$ & $19.83 \mathrm{cC}$ & $23.33 \mathrm{aB}$ & $24.83 \mathrm{aC}$ & $21.50 \mathrm{bB}$ & $17.66 \mathrm{dC}$ \\
\hline
\end{tabular}

Means followed by same small letter (row) and capital letter (column) did not differ significantly by DMRT at 5\% level of probability.

\section{Seed yield}

Seed yield per plant was significantly affected by genotypes and $\mathrm{N}$ fertilizer applications. Seed yield of mungbean varied from $7.33 \mathrm{~g}$ to $14.22 \mathrm{~g} \mathrm{plant}^{-1}$ (Table $3)$ and it was the maximum in IPSA $12\left(14.22 \mathrm{~g} \mathrm{plant}^{-1}\right)$ grown with $60 \mathrm{~kg} \mathrm{~N} \mathrm{ha}^{-1}$ and the lowest in ACC12890053 (7.33 $\mathrm{g} \mathrm{plant}^{-1}$ ) followed by Bina moog 5 under control condition. The genotype IPSA 12 also well responded (11.32 $\left.\mathrm{g} \mathrm{plant}^{-1}\right)$ under control condition. There was general trend of increase in seed yield with the increase of $\mathrm{N}$ fertilizer but it was at par with $60 \mathrm{~kg} \mathrm{~N} \mathrm{ha}^{-1}$ and thereafter decreased the seed yield of mungbean. Among the tested mungbean genotype IPSA 12 produced highest seed yield in control condition. So, genotype IPSA 12 might be considered as suitable genotype in nutrient stress soil. These findings agreed with Biswas and Hamid (1989) and Mitra and Ghildiyal (1988) that seed yield of mungbean is limited by nitrogen supply. Application of $\mathrm{N}$ fertilizer 
enhanced leaf area, dry matter production and yield component which consequently improved yield of mungbean genotypes.

Table 3. Seed yield $\left(\mathrm{g}_{\text {plant }}{ }^{-1}\right)$ of mungbean genotype as affected by nitrogen fertilizer

\begin{tabular}{l|ccccccc}
\hline \multirow{2}{*}{ Genotypes } & \multicolumn{7}{c}{ Nitrogen level $\left(\mathrm{kg} \mathrm{ha}^{-1}\right)$} \\
\cline { 2 - 7 } & $\mathrm{N}_{0}$ & $\mathrm{~N}_{20}$ & $\mathrm{~N}_{40}$ & $\mathrm{~N}_{60}$ & $\mathrm{~N}_{80}$ & $\mathrm{~N}_{100}$ \\
\hline IPSA 12 & $11.32 \mathrm{Ac}$ & $11.87 \mathrm{Ac}$ & $12.87 \mathrm{Ab}$ & $14.22 \mathrm{Aa}$ & $12.41 \mathrm{Ab}$ & $10.80 \mathrm{Ac}$ \\
GK-27 & $10.97 \mathrm{Ab}$ & $12.34 \mathrm{Aa}$ & $12.80 \mathrm{Aa}$ & $12.61 \mathrm{Ba}$ & $11.94 \mathrm{Ab}$ & $10.43 \mathrm{Ab}$ \\
IPSA 3 & $10.78 \mathrm{Abc}$ & $11.83 \mathrm{Ab}$ & $12.82 \mathrm{Aa}$ & $13.32 \mathrm{ABa}$ & $11.65 \mathrm{Ab}$ & $10.35 \mathrm{Ac}$ \\
IPSA 5 & $9.60 \mathrm{Bc}$ & $11.72 \mathrm{Ab}$ & $12.45 \mathrm{Aa}$ & $13.64 \mathrm{Aa}$ & $12.36 \mathrm{Aa}$ & $10.10 \mathrm{Abc}$ \\
ACC12890055 & $9.33 \mathrm{Bc}$ & $11.90 \mathrm{Aab}$ & $11.81 \mathrm{Bab}$ & $12.29 \mathrm{Ba}$ & $10.93 \mathrm{Bb}$ & $9.87 \mathrm{ABb}$ \\
GK-63 & $10.06 \mathrm{Bb}$ & $12.00 \mathrm{Aa}$ & $12.20 \mathrm{Ba}$ & $13.09 \mathrm{Ba}$ & $11.99 \mathrm{Aa}$ & $9.23 \mathrm{ABb}$ \\
ACC12890053 & $7.33 \mathrm{Dcd}$ & $8.49 \mathrm{Db}$ & $9.12 \mathrm{Cab}$ & $9.60 \mathrm{Ca}$ & $9.31 \mathrm{BCab}$ & $7.95 \mathrm{Cc}$ \\
BU mug 4 & $8.93 \mathrm{Bbc}$ & $10.35 \mathrm{Bab}$ & $11.14 \mathrm{Ba}$ & $10.85 \mathrm{Ba}$ & $10.40 \mathrm{Bab}$ & $9.59 \mathrm{ABbc}$ \\
BARI Mung 6 & $8.55 \mathrm{Bbc}$ & $10.78 \mathrm{Bb}$ & $11.82 \mathrm{Bab}$ & $12.84 \mathrm{Aa}$ & $12.40 \mathrm{Aa}$ & $11.24 \mathrm{Aab}$ \\
Bina moog 5 & $7.48 \mathrm{Dc}$ & $8.61 \mathrm{Cb}$ & $9.31 \mathrm{BCab}$ & $10.23 \mathrm{Ca}$ & $9.71 \mathrm{Cab}$ & $8.37 \mathrm{Cbc}$ \\
\hline
\end{tabular}

Means followed by same small letter (row) and capital letter (column) did not differ significantly by DMRT at 5\% level of probability.

\section{Conclusion}

The results revealed that nitrogen is necessary to ensure better growth and productivity of different mungbean genotypes under nutrient stress soil. But the genotype IPSA 12 performed better in nutrient stress soil where $60 \mathrm{~kg} \mathrm{~N} \mathrm{ha}^{-1}$ is optimum for better crop growth and development

\section{References}

Aktharuzaman, M. A. 1998. Influence of rate of nitrogen and phosphorus fertilizers on the productivity of mungbean (Vigna radiata). A $\mathrm{Ph} D$ thesis submitted to Department of Agronomy, IPSA, Gazipur.Pp: 65

Anjum, M. S., Z. I. Ahmed and C. A. Rauf. 2006. Effect of Rhizobium inoculation and nitrogen fertilizer on yield and yield components of mungbean. Int. J. Agric. and Biol. 8: 238-240.

Ashraf. M. 2001. Influence of seed inoculation and NPK application on growth, yield and quality of mungbean (Vigna radiata L.Wilczek) cv. NM-98. M Sc Thesis, Department of Agronomy . University of Agric. Faisalabad, Pakistan. Pp:41

Biswas, J. C and A, Hamid. 1989. Influence of carbofuran on leaf senescenes and nitrogen uptake of mungbean (Vigna radiata) Bangladesh J. Agric. 14: 261-267. 
Chanda, M. L. 2007. AVRDC's Role in expanding mungbean production in south Asia. A paper presented in National Workshop in Pulses, held in BARI, Joydebpur, Gazipur. P. 29.

Dahatonde, B. N and R. V. Nalamwar. 1996. Effect of nitrogen and irrigation levels on yield and water use of French bean (Phaseolus vulgaris). Indian J. Agron. 4: 265268.

Gimenez, C., D. J. Corror and F. Rueda. 1994. Canopy development, photosynthesis and radiation use efficiency in sunflower in response to nitrogen. Field Crops Res. 38: $15-27$.

Karmer, P.J. 1988. Water stress and plant growth Agron. J. 55: 31-35.

Mahboob, A and M. Asghar. 2002. Effect of seed inoculation and different nitrogen levels on the grain yield of mungbean. Asian J. Plant Sci. 1: 314-315.

Matsunaga, R., B. B. Singh., M. Sdsmou., S. Tobita, K. Hayashi and A Kamidohzono. 2008. Yield performance, Nitrogen and Phosphorus acquisition of cow pea germplasm accession in low fertile sandy soils in sahelon zone. Trop.Agr. Develop. 52: 50-57.

Mitra, S and M. C. Ghildiyal. 1988. Photosynthesis and assimilates partitioning in mungbean in response to source sink alterations. J. Agron and Crop Sci. 160: 303-308.

Patra, F. M and L. R. Patel. 1991. Response of greengram varieties to phosphorus and rhizobium inoculation. Indian A. Agron. 36:355-356.

Patra, D. K and P. Bhuttacharyya. 1997. Influence of root nodule bacterium on nitrogen fixation and yield of mungbean. J. Mycopathol. Res. 35: 47-49.

Sinclair, T. R and V. Vadez. 2002. Physiological traits for crop yield improvement in low $\mathrm{N}$ and $\mathrm{P}$ environments. Plant and Soil. 245:1-15.

Sushant, R. S. Dixit and G. Singh. 1999. Effect of irrigation, nitrogen and phosphorus on seed yield and water use of rajmash (Phaseolus vulgaris). Indian J. Agron. 44: 382-388.

Vos, J and P. E. L. V. D. Putten.1998. Effect of nitrogen supply on leaf growth, leaf nitrogen economy and photosynthetic capacity of potato. Field Crops. Res. 59: 63-72. 
